Abstract

\title{
Genetic Variation of Candidate Genes for Timing and Effectuating Photoperiodic Diapause Induction in the Parasitoid Nasonia vitripennis ${ }^{\dagger}$
}

\author{
Pauline Romeyer, Leo Beukeboom and Louis van de Zande
}

Citation: Romeyer, P.; Beukeboom, L; van de Zande, L. Genetic Variation of Candidate Genes for Timing and Effectu-ating Photoperiodic Diapause Induction in the Parasitoid Nasonia vitripennis, in Proceedings of the 1st International Electronic Conference on Entomology, 1-15 July 2021, MDPI: Basel, Switzerland, doi:10.3390/IECE10577

Published: 2 July 2021

Publisher's Note: MDPI stays neutral with regard to jurisdictional claims in published maps and institutional affiliations.

Copyright: (c) 2021 by the authors. Submitted for possible open access publication under the terms and conditions of the Creative Commons Attribution (CC BY) license (http://creativecommons.org/licenses /by/4.0/).
University of Groningen

* Correspondance: ttalebkarima@yahoo.fr

+ Presented at the 1st International Electronic Conference on Entomology (IECE 2021), 1-15 July 2021; Available online: https://iece.sciforum.net/.

\begin{abstract}
Seasonal variation of photoperiod and temperature often leads to a latitudinal gradient in season-dependent behavior. The parasitic wasp Nasonia vitripennis exhibits a latitudinal cline in photoperiodic diapause induction. Allelic variation of the clock gene period was shown to be associated with this behavioral cline. In addition, circadian expression of the clock genes period (per), cryptochrome-2 (cry-2), clock (clk), and cycle (cyc) shows photoperiodical and latitude-of-origin associated variation. Apart from these clock genes, a Genome Wide Association Study revealed five possible non-clock effector genes for diapause induction: Helicase DDX28, APC11, SIPA1L1, OR175, and CBFA2TI. Here we use sequence data of isogenic N. vitripennis lines from different latitudes to screen for variation in these additional clock and non-clock candidate genes for photoperiodic diapause induction. Polymorphisms in cry-2, cycle and SIPA1L1 showed a haplotype distribution according to latitude-of-origin. Our results support a role of clock gene and SIPA1L1 variation in the difference of diapausing brood production of the northern and southern lines and hints at different selection pressures for diapause effector genes in high end low latitudes.
\end{abstract}

Keywords: parasitoid wasp; photoperiodic diapause; circadian clock; effector genes; seasonal adaptation; latitudinal effect; single nucleotide polymorphisms (SNPs) 